\title{
The Transforming Impact of Collective Action: Belgium, 1886*
}

\author{
GITA DENECKERE
}

\begin{abstract}
Summary: This article illuminates the transforming impact of collective action in the light of the industrial jacquerie of 1886 in Belgium. This important episode of popular struggle fuelled a dialectical process of change which was marked by a fundamental shift in both social policy and in repertoires of collective action. In 1886 workers still drew on an old repertoire of collective action. Their struggle had such a disruptive force that it forced the state to intervene in labour conflicts. The conservative political élite responded with conciliatory gestures that foreshadowed a legislative programme of social reform. In the changed political climate the position of progressive wings in the two conservative parties was enhanced as the growing strength of the labour movement became more apparent. The industrial jacquerie functioned as a catalyst in the transition from old to new repertoires of collective action. In the aftermath of the revolt, mass collective action quickly, and extensively, came under the control of the Parti Ouvrier Belge (POB).
\end{abstract}

The problem: "Who built Thebes and its seven gates?"

At the top of the "history from below" agenda is the idea that the lower classes did not merely undergo their historical fate, but instead played an active role in making their own history. Riots and collective actions of all kind have proved to be exquisite laboratories for the exploration of this idea. Oddly enough, the question to what extent ordinary people succeeded in making and changing history by acting collectively has hardly been posed. The question is very important, however, because actions, since they speak more loudly than words, may tell us a great deal about the power of ordinary people who have left almost no written records of the history they made.

In a wide-ranging and extended critique of the literature, Sidney Tarrow perceptively notes that few studies explicitly investigate the causal relations between protest and reform, and he goes on to explore the wave-like fluctuations in both protest and reform. He correctly observes that it is

*I am greatly indebted to Herman Balthazar, Catharina Lis, Hugo Soly, Carl Strikwerda, Wayne Te Brake and Louise and Charles Tilly for their critical, helpful comments on earlier drafts of this article.

International Review of Social History 38 (1993), pp. 345-367 
difficult to find much in the literature regarding the success of social movements in bringing about social or policy change. This flaw is remarkable since the concept of change is at the core of all definitions of protest and social movements. ${ }^{1}$ Tarrow returns in fact to the question Piven and Cloward posed in 1977, a question largely left unanswered by subsequent scholars. $^{2}$

The stress on the relations between the actions of ordinary people and the varying responses of representatives of the state - who hold the levers of reform - sheds new light on Charles Tilly's recent endeavours to make short work of the conceptual fallacies in single-actor models of collective action. ${ }^{3}$ His "repertoires" of collective action highlight the dynamic interactions between challengers and authorities, allies and enemies in a political arena that changes over time. Tilly shows how, up to the middle of the nineteenth century, the repertoire of ordinary French people was essentially local ("parochial") in scope and patronized by local authorities. Local communities or corporations addressed powerful local patrons to mediate in conflicts with national élites. From the middle of the nineteenth century onwards, roughly speaking, the "old" forms of collective action (food riots, land invasions, destruction of toll gates, charivari, machinebreaking, and turnouts, for example) were gradually replaced by a "new" repertoire. The "new" forms of collective action (strikes, demonstrations, electoral assemblies, public meetings, social movements) were no longer local and patronized, but national and autonomous. Ordinary people expressed specific claims and grievances through representative and formal organizations. ${ }^{4}$

The relationship between collective action and the state has, however, not yet been fully explored. Tilly's question is: how did huge structural changes (proletarianization, state formation) shape new repertoires of collective action? The question may be put the other way round as well, though. How did the actions of ordinary people shape social and political change? Sidney Tarrow advances a compelling hypothesis: "To the degree that reform cycles depend on cycles of collective action, political involvement and protest, then reformism can not be attributed to the decisions

' Sidney Tarrow, Struggle, Politics and Reform: Collective Action, Social Movements and Cycles of Protest (Cornell, 1989) [Cornell University, Western Societies Program, Occasional Paper No. 21].

2 Frances Fox Piven and Richard A. Cloward, Poor People's Movements: Why They Succeed, How They Fail (New York, 1977).

${ }^{3}$ Charles Tilly, "Models and realities of popular collective action", Social Research, 52 (1985). pp. 717-747; Charles Tilly, "The analysis of popular collective action", European Journal of Operational Research, 30 (1987), pp. 223-229; Charles Tilly, "Social movements, old and new" in Louis Kriesberg et al., Social Movements as a Factor of Change in the Contemporary World (Greenwich, Connecticut, 1988) [Research in Social Movements, Conficts and Change, vol. 10], pp. 1-18.

- Charles Tilly, The Contentious French: Four Centuries of Popular Struggle (Cambridge, Mass., 1986). 
of enlightened statesmen but depends upon the stimulation of pressures from below."s

The reciprocal interactions between the challengers and authorities involved in collective action leave traces in the sources and reflect the link between protest and reform. We must pay closer attention to the position of the elites and ask whether, how and why their political strategies changed as a result of protest and collective action.

This article attempts to illuminate the transforming impact of collective action in the light of a major episode of popular struggle in Belgium: the industrial jacquerie of 1886 . The consequences of this disruptive event will be analysed to show how it fuelled a dialectical process of change marked by a fundamental shift in social policy as well as in repertoires of collective action. I present a narrative of the events of March 1886 and try to show that in $\mathbf{1 8 8 6}$ workers still drew on an "old" repertoire of collective action. They did so with such a disruptive force that workers" grievances could no longer be ignored by the national authorities. Their grievances were channelled into less dangerous forms of political expression and bargaining. The conservative political élite responded with conciliatory gestures that foreshadowed a legislative programme of social reform. In this changed political climate, the position of the social-progressive wings of the two conservative parties was strengthened as the growth and influence of the Parti Ouvrier Belge (POB) became more visible. These results all demonstrate the power of protest to set the political agenda.

As to the cumulative impact of protest and reform on the recently founded $P O B$, the mass base of support needed to constitute a genuine social movement was mobilized shortly after. The revolt of 1886 is a major illustration of the interactive process between collective action and organizations that is at the core of what Tarrow calls the oldest and most unresolved question in the study of collective action, namely, under what conditions mass collective action comes under the control of these organizations. ${ }^{6}$ After 1886 mass collective action rapidly and extensively came under the control of the POB. The repertoires of working-class collective action changed significantly in the aftermath of the industrial jacquerie. How and why?

\section{A case in point: the industrial jacquerie of 1886}

The winter of 1885-86 undoubtedly marked the peak of the economic depression which had begun to hit Europe in 1873. Belgium's industrialized regions were extremely vulnerable since they depended heavily on the export of coal and iron. After England, Belgium was the largest industrial giant in Europe during the early years of industrialization, with a

Tarrow, Struggle, Politics and Reform, p. 103.

6 Ibid., pp. 17-20. 
factory system which was concentrated in distinct regions. Industrialization was relatively advanced in the Walloon provinces of Liège and Hainaut, whereas in Flanders only the city of Ghent was of modern industrial significance. The Great Depression was obviously not going to help improve the already grim living conditions of the miners, metal workers and glassblowers of Liège and Hainaut. A sharp decrease in levels of real wages at the same time as massive unemployment and labour-saving investment in the technological innovations of the Second Industrial Revolution - the internal combustion engine, the turbine, the use of petrol and electricity, the substitution of coal by gas and iron by steel - set the scene for the battle.

A few days before the public and the politicians were shaken out of hibernation, an obscure body of anarchists invited the workers to celebrate the fifteenth anniversary of the Paris Commune by joining a demonstration to be held in Liège on $18 \mathrm{March}$. In a pamphlet published to mobilize support, they accused their compagnons of "culpable apathy", referring to the popular disturbances in London, Amsterdam and New York that year. The liberal mayor of Liège, who did not expect any disorder, authorized the demonstration. A few weeks before, he had been visited by the secretary of the recently founded anarchist group. The mayor was then informed that the anarchist committee was composed of twelve members and that its audience was typically no larger than forty. Nobody actually anticipated the resonance the demonstration would have. Even the organizers were surprised by the multitude of the employed and unemployed who came all the way from the suburbs of Liège to where the demonstrators were to gather. After the demonstration, a public meeting was planned in a pub called the "Café National". The Café National held only 300 people, while the crowd gathering in the streets of Liège exceeded this figure almost three times. Around eight o'clock in the evening, the demonstration moved off chanting "Vive la Commune, A bas les riches, A bas les capitalistes." It did not take long before the first windows were smashed with the poles of the red flags being carried by the demonstrators. The crowd chose to target shops, especially those of jewellers and other symbols of luxury. A bakery was pillaged. A man shouted "Toutes les marchandises dans les magasins, vous les faites et vous n'en jouissez pas! Vous mourez de faim avec vos femmes et vos enfants et vous laissez la toutes ces richesses [ . . . ] Vous n'etes que des laches!" Neither the police present, who were unable to repress such large-scale discontent, nor the first speaker at the meeting, who eschewed revolutionary discourse, succeeded in quieting the commotion. It seems as if the sinewy language of a certain Wagener (a radical chair-maker, who had named his son Spartacus and his daughter Louise-Michel), the next speaker in the Café National, produced more effect, despite the fact that most of the demonstrators were unable to hear him. "Les propriétaires, nom de Dieu, c'est avec la dynamite qu'il faut les traiter!" Things did not go that far, though 
the insurgents, as they were called in the newspapers, ruled the streets until midnight. The mayor issued a proclamation prohibiting gatherings of over five persons and called for the citizen guard to intervene. Several people were arrested.

The twentieth of March saw the first signs of an increasingly widespread strike in the industrial basin of Liège (Tilleur-Flémalle, Ougrée-Seraing). It is most unlikely, however, that the disturbances in Liège on 18 March put the spark to the tinder. Many mine-owners and surveyors had anticipated the strike on the basis of what had happened on earlier occasions. Because 20 March was pay-day in a number of mines, wage cuts portended collective protest. ${ }^{7}$

From 25 March onwards, the same phenomenon occurred in the basin of Charleroi, pay-day falling on 24 March in the mine where the strike first broke out. A similar process of "collective bargaining by riot", by no means extraordinary in itself, announced the beginning of a strike movement in both industrial regions. Let us take a close look at how support developed for the collective actions in the basin of Charleroi and at subsequent events, without which the revolt of 1886 would never have acquired its historical significance. ${ }^{8}$

On 25 March at 6 a.m. about 200 miners in Fleurus refused to go down the pit; they were discontented with yet another wage cut the day before. They went to other coal mines in the neighbourhood. Their action extended to the north-east of Charleroi, progressively gaining strength. The tactic was the same in every mine: the leaders of the band entered the pithead, ordered the engineers to shut down the engines, and forced the miners below ground to come up by threatening to shut down the ventilator, cut the cables, and push the wagons down the mine-shafts. They succeeded everywhere; the gendarmes were incapable of assuring $l a$ liberte du travail. The authorities held an emergency meeting in Charleroi. They feared an invasion of the city and took preventive measures. But the miners were not at all interested in the political centre of the region.

The next day, $26 \mathrm{March}$, the degree of organizational capacity possessed by the industrial workers became clearer. The action started at 9 a.m. with a mass meeting in Gilly. Two thousand men, women and children assembled on the market square; a number of them were armed with cudgels, pickaxes, iron bars and the like. Gilly is situated at a strategically important crossing, Quatre Bras, where the road between Lodelinsart and Châtelet intersects the main road from Charleroi to Gembloux. The large group of workers recruited from the north-eastern periphery of Charleroi who were already on strike split up into three bands, each marching in a

? Archives de l'Etat Liège, Sareté publique de la province de Liège, XIV.

- The story is based on eyewitness accounts reproduced in Gustave Houdez, Quatre-vingt-six. Vingt-cinq ans après (Frameries, 1911); Jean Lefèvre and Daniel Misonne, "Témoins châtelettains des événements sociaux de 1886 dans le pays de Charleroi", Le Vieux Chatelet, 25 (1985), pp. 57-92; and on contemporary press reports. 
different direction: north-west (Lodelinsart, Jumet), south-west (Charleroi, Damprémy, Marchienne-au-Pont, Monceau, eventually going north to Roux), and south-east (Châtelet, Couillet, Acoz). The mobilization achieved the previous day in the coalmines was now echoed in iron foundries, steelworks, forges and glassworks as well. The police commissioners of the municipalities were asked to report on the events by the Royal Attorney of Charleroi. ${ }^{9}$

By the afternoon, Charleroi was surrounded by a network of mines and factories whose workers were prepared to support the protest. This was unlikely to have happened without organizational skills and experience. The Minister for War, who eight months later was called by parliament to account for the belated intervention of the army, denied that even though the bands had threatened to cut the ropes of the mineshafts if the miners did not stop work, nothing suggested the movement would be different from the sort of strikes that were so common in the region. ${ }^{10}$

The violence used by the strikers cannot be described as blind or mindless. Factories and mines became targets of verbal violence only because they held the key to the recruitment necessary for the successful mobilization. But the glassworks, which flourished in the region of Charleroi, would appear to have been far more symbolic targets. The principal glassworks was owned by Eugène Baudoux, a self-made man who, just before 1886 , had been the first to apply a new technological process. The application of this new technology caused profound industrial and social changes. By substituting gas for coal, the new type of furnace required much less fuel, thus threatening the regional coal industry, which was already so vulnerable because of the Great Depression. The new type of furnace was labour-saving as well. It permitted an increase in productivity by the division of labour into shifts and the employment of semi-skilled industrial proletarians. The glassworkers, especially the specialized glass-blowers, a prosperous labour aristocracy, found their interests severely threatened. The issue is one which has received much attention in the literature. ${ }^{11}$ Until the 1880s the glassworkers had not been affected by the process of deskilling to which other categories of artisans had fallen victim as industrialization progressed. As long as their skill was indispensable to the

- The Royal Attorney asked among other things, whether the strike had broken out "spontaneously" in their municipality. An example: "A Damprémy se sont mis en grève forcément dans tous les établissements, verreries, tréfilleries, charbonnages (les 4 fosses) attendu que les bandes de grévistes étrangers ont venu envahir les établissements, le 26 Mars de une heure de relevée à 6 heures du soir. Mais les houilleurs surtout s'y attendaient, car a la remonte des ouvriers a 3 heures [ . . on a entendu dire: . . . ] Ah, on y est; bonne affaire sì cela réussit." Archives Générales du Royaume à Bruxelles, Parquet-Général de Bruxelles, 238-239.

${ }_{10}$ Annales Parlementaires, 1886-1887, p. 290.

1 See, for instance, Dick Geary, European Labour Protest 1848-1939 (London, 1981); Eric J. Hobsbawm, "Artisan or Labour Aristocrat?" The Economic History Review, 3 (1984), pp. 355-372; and Joan Scott, The Glassworkers of Carmaux (Cambridge, Mass., 1974). 
production process and their craftsmanship was valued by society, the glassworkers could continue to monopolize the trade and to have a strong bargaining position $v i s-d \cdot v i s$ their employers. The strong ties between skill, privileges and high wages produced high social status and independence, things the unskilled labourer lacked. The technological innovations of the Second Industrial Revolution and the increased mechanization and division of labour also threatened skills.

The Charleroi glassworkers responded to these social threats in a way similar to that of the glassworkers of Carmaux: they created a syndical organization. ${ }^{12}$ In 1882 , the Union Verriere was founded. In 1884, the organization joined the Knights of Labor of America. In March 1886, the Union Verrière was involved in a serious conflict with the employers, in particular with Eugène Baudoux. The latter had imposed a wage cut and had furthermore claimed to be able to teach the skills needed in his glassworks rapidly and efficiently to the sons of miners; these two acts, demonopolizing the glassworkers' traditional control of wage levels and entry to the craft through apprenticeship and hereditary succession, were highly provocative.

The conflict did not end with institutionalized bargaining between Baudoux and the Union Verrière. Since Eugène Baudoux personified the technological and social changes being made, on 26 March his modernized glassworks was selected as the chief, though certainly not the only target of a latter-day Luddism. The leaders of the Union Verrière had neither planned this kind of action nor encouraged the rank and file to act. Instead the Union Verrière held meetings (on 15, 20 and 22 March) articulating the workers' grievances and organized itself to regain a strong bargaining position in its struggle with management. The resort to an old, violent and direct form of collective action had become a rare phenomenon indeed. Viewed from a distance, destroying machines did not actually fit into the repertoire of actions characteristic of formal organizations like the Union Verrière.

Baudoux anticipated something would happen, so he locked out his 1,200 workers early in the morning. But the band of protesters coming from Gilly that had entered the centre of the glass industry was not only swollen with glassworkers, it also left behind a path of destruction in other glassworks that had installed the new furnaces. The selectivity of the violence must be underscored: the ateliers of the artisan glassworkers were not targets at all.

What happened next was described by an eyewitness as an unforgettable spectacle. In less than half an hour everything in the factory was completely and expertly destroyed; there could be no doubt about the professional origins of the machine-breakers. Then the glassworks was set on fire. Under a

12 Joan Scott, The Glassworkers of Carmaux, pp. 72-107; Jean Neuville, Naissance et croissance du syndicalisme. 1. L'Origine des premiers syndicats (Brussels, 1979), pp. 191-209. 
red-hot sky and watched by 5,000 spectators, including gentlemen wearing hats who did nothing to prevent what was taking place,,$^{13}$ the crowd broke into Baudoux's sumptuous château. The furniture and the bedlinen were thrown out of the windows, mantlepieces were ripped out, chandeliers smashed, and the cellar was pillaged. Eventually the château was set ablaze. Around the sea of flames, a revival of the saturnalia was enacted. The crowd emptied bottles of champagne, dressed up in the high hats of Baudoux and the gowns of his wife, and men and women danced around the sea of flames. The thirty soldiers guarding the chateau were powerless in the face of such a scene, and they were forced to flee under a hail of stones.

In Roux, an equally significant incident announced the dramatic end of the revolt. One of the two other mobs departed that morning from Gilly and arrived in Roux in the early evening. A delegation of strikers demanded an interview with Monseu, the manager of the local glassworks. The scenario was similar; violent threats were made, the head office was set on fire, and 5,000 metres of glass smashed. Eventually, at 11 p.m., the troops arrived. The collision between the soldiers and the rioters was as inevitable as it was fortuitous. The police commissioner legalized the subsequent shooting of protestors by ordering the crowd to disperse. Four workers were killed, dozens were severely wounded. On 27 March the region of Charleroi was put under martial law. ${ }^{14}$ The government had charged Lieutenant-General Van der Smissen with restoring law and order, a task he performed with an iron hand. Van der Smissen considered shooting in the air absurd and authorized the citizens to arm and defend themselves against the numerous strikers (he called them brigands) traversing the region in search of food. In Roux, the tragedy of the previous night recurred. "Cette fois, dix cadavres restent sur la chaussée", the Lieutenant-General observed coldly. ${ }^{15}$ This time, no warnings were given. The events of March 1886 cost the lives of twenty-eight proletarians, most of them miners aged between seventeen and twenty-four.

\section{"Old" repertoires of collective action}

Current interpretations of the industrial jacquerie of 1886 take economic deprivation as a starting point, and are often in terms of traditional ideas

${ }^{13}$ Clearly, the smaller patrons within the glass industry, who could not afford to innovate, were equally threatened by an entrepreneur like Baudoux. It has been said that they paid the rioters to steal industrial secrets.

14 A detailed account of this can be found in Jan Verhaeghe, "De ordehandhaving bij de sociale onlusten in maart-april 1886 in Luik en Henegouwen", Belgisch tijdschrift voor militaire geschiedenis - Revue belge d'histoire militaire, 25 (1984), pp. 687-724; 26 (1985) pp. 1740; 27 (1986), pp. 435-464; 28 (1989), pp. 269-298.

15 Van der Smissen (Lieut.-Gén.), "Rapport confidentiel sur la répression des troubles dans les provinces de Liège et du Hainaut en mars et en avril 1886", Musée Royale de l'Armée, Tussenkomst van de gewapende machten bij de ordehandhaving B256. 
about collective violence. The underlying assumption is clearly the existence of a strong causal relationship between material deprivation, frustration and aggressive violence. Some historians have plainly adopted the diagnosis of contemporary observers as well, describing the event as a spontaneous, irrational outburst of violence following a period of accumulated misery and, in political terms, as absolutely aimless and blind.

At a second glance, however, another picture emerges. What seemed a rather abstract "volcanic" outburst of popular outrage actually consisted of specific collective actions, based upon the organizational capacities of a set of people not yet formally organized in the then still very weak Parti Ouvrier Belge (POB).

Historians connecting the demonstration in Liège, the miners' strikes in the regions of Liege and Charleroi, and the violent attacks on the symbols of technological innovation in the glass industry - three occurrences of collective popular action having no strict unity of time and place - interpreted them as a spontaneous drama of the deprived, lacking any organization or purpose. ${ }^{16}$ The weakness of this kind of interpretation is that it projects present-day repertoires of collective action on to the past. The misconception is probably also due to the fact that no formal organization, like the $\mathrm{POB}$, acted as a co-ordinating unit, declaring or organizing the strike. On the contrary, the POB stressed time and again the impulsiveness and the inconsiderate violence of the Walloon proletariat. Though the Walloon mass labour movement was still in its infancy, this does not imply that the industrial proletariat of Liège and Hainaut had not developed other kinds of organization, albeit local and informal. Historians have overlooked these older forms of action, which were different from modern routines. In order to contrast these old routines with the new ones adopted after 1886 and to show that Charles Tilly's idea of changing repertoires of collective action is supported by the Belgian context, the old Belgian working-class repertoire must be examined. Relevant to the case study here is the so-called turnout, machine-breaking and the local scope of collective actions.

\section{Turnout}

The tactic which gave most collective actions in 1886 an organized form is reminiscent of a tactic that has no name in Dutch or in French, Belgium's two official languages. In English, it is known as "turnout". Tilly describes the pattern of turnouts, belonging to an old repertoire of collective action, as

${ }^{16}$ See, for instance, the only synthesis on popular action in Belgium up to the present: Frans Van Kalken, Commotions populaires en Belgique 1834-1902 (Brussels, 1936) p. 97. Van Kalken writes: "Rien ne prouve peut-être mieux que le mouvement de 1886 fut "un sursaut de fureur collective, sans plan préconçu, sans direction, sans but précis" [the quote is from H. Pirenne] que ce fait: huit jours s'écoulèrent avant le pays de Charleroi se prît a imiter le mouvement né dans le pays de Liége." 
the routines by which workers of a given craft who had a grievance against the employers of their locality went from shop to shop within the locality, calling out the workers to join them in a march through the town, ended the circuit with a meeting at the edge of town, voted to make a certain set of demands, sent a delegation to the employers, declared a work stoppage, and enforced it as best as they could throughout the town until they reached an agreement with the employers. The turnout was relatively local in scope. It put pressure on nearby patrons - both the employers and the local authorities. ${ }^{17}$

A turnout was usually accompanied by threats. These could be carried out when employers refused to stop production, or when employees did not dare or want to join the aggrieved workers. The "turnout mob" would then enforce the solidarity they sought.

Although no Dutch or French equivalent for the word "turnout" exists, this particular form of popular collective action was defined "from above" in a notorious article of the Belgian penal code, article 310. Article 310 runs as follows:

Sera puni d'un emprisonnement de huit jours à trois mois et d'une amende de 26 frs. à 1000 frs., ou d'une de ses peines seulement, toute personne qui, dans le but de forcer la hausse ou la baisse des salaires ou de porter atteinte au libre exercice de l'industrie ou du travail, aura commis des violences, proféré des injures ou des menaces, prononcé des amendes, des défenses, des interdictions, ou toute proscription quelquonque, soit contre ceux qui travaillent, soit contre ceux qui font travailler. Il sera de même de tout ceux qui, par des rassemblements près des établissements où s'exerce le travail, ou près de la demeure de ceux qui le dirigent, auront porté atteinte à la liberté des maîtres ou des ouvriers.

Article 310 was introduced in 1866 to replace the article that suppressed coalitions of workers, whether formally organized or not. The prohibition of "coalitions" enabled the forces of law and order to act repressively against organizations of workers and their collective actions alike. Labour associations were legalized in Belgium in 1866. But legislation continued to criminalize by far the most important weapon available to workers, the strike. This was achieved through article 310 , which until its repeal in 1921 considerably constrained the breadth of collective popular action. It covered the repression of organization by action, which, given the lack of powerful organizational infrastructures until at least the 1890 s, was usually the only efficient means to add force to workers' demands. Individual liberty, embodied in the "freedom to work" (liberté du travail), provided the ideological legitimation for the laissez-faire state to suppress this routine. Article 310 was a powerful and arbitrarily applied political instrument condemning the strike to a de facto illegal mode of collective popular action. It is not surprising that around 80 per cent of the more than 600 people arrested on the occasion of the insurrection in 1886 were accused of "crimes" directly related to the process of mobilizing support. ${ }^{18}$ In both

17 Tilly, The Contentious French, p. 394.

18 Joseph A. Frank, "L'insurrection belge de 1886: 'une jacquerie industrielle' vue comme action para-politique", Revue de l'Institut de Sociologie, 1-2 (1975), p. 181. 
Liège and Charleroi the strikers were mainly mobilized by "turnout mobs".

It might be argued that the turnout seems too old a tradition to be effective in a social context with large numbers of semi-skilled and unskilled industrial workers and sharp divisions between capital and labour. Some characteristic features, like its local scope and its limitation to a given craft, were exceeded by the industrial workers in 1886 . But the miners, who started the strike in the first place, were acquainted with the frequent use of this kind of mobilization. Most of the strikes evolving in the distinct industrial regions of Wallonia were in fact produced through a pattern similar to the turnout-routine, thereby growing in amplitude and frequency after the middle of the nineteenth century. ${ }^{19}$ In the heavily industrialized provinces of Wallonia at least, turnouts were transformed into strikes without losing the informal capacity to mobilize; they obtained a regional scope and amplitude, though. Working-class collective action remained aimed at local employers and authorities in these regions, though also at the corporate owners of mines and iron-and-steel works as a whole, following the concentration of capital in large, anonymous companies. Charles Tilly concludes that in France from the 1850s onwards the concentration of capital and the increase in the scale of the labour market rendered the old forms of working-class collective action ineffective and promoted workers' organizations at the scale of the firm. ${ }^{20}$ Although in other industrialized parts of Belgium (Ghent, Brussels) there was indeed an increase in the number of firm-based strikes after 1860 , workers in the Walloon industrial basins resorted mainly to region-wide collective action that was structured and extended by means of turnout-routines. This repertoire remained dominant in Wallonia until late into the nineteenth century, despite article 310 and despite the endeavours of labour associations and doctrines imported from outside the region, particularly in the $1860 \mathrm{~s}$ and $1870 \mathrm{~s}$, the period of the First International. The First International proved unable to control the collective actions of the Walloon industrial workers, whom it was trying to organize on a modern basis.

\section{Machine-breaking}

Perhaps the persistence of a relatively old repertoire corresponding to a lack of formal labour organizations accounts for the violence against property in March 1886. The turnout - in itself a non-violent form of collective action - had more chance of leading to violence than a strike organized by labour associations with financial backing. Its illegality promoted violent

19 L. Henneaux-De Pooter, Miseres et luttes sociales dans le Hainaut, 1860-1869 (Brussels, 1959); Jacques Pauwels, "Werkstakingen in Belgix, 1830-1873" (unpublished thesis, University of Ghent, 1969); Jean Puissant, L'évolution du mouvement ouvrier socialiste dans le Borinage (Brussels, 1982).

20 Tilly, The Contentious French, pp. 271-272. 
encounters with police forces. But, all in all, the turnouts in 1886 did not actually lead to much violence; most miners were willing to join and most employers were scared to resist. The turnouts were also likely to grow in strength since the forces of law and order present were too weak to suppress them. The diffusion of the protest movement to other industrial sectors, such as metal-working factories and glassworks, was probably a result of the collective enthusiasm produced by the success of mobilization itself. It is plausible that the glassworkers would not have acted collectively as violently as they did in defence of their interests and lost prerogatives if they had not been mobilized by the miners. The subsequent machinebreaking, the destruction and burning of the newly renovated glassworks, and the saturnalia at Baudoux's château leave us with the image of an industrial jacquerie. Such violent attacks on property and machinery clearly belong to an old repertoire of collective action. Machine-breaking is indeed often associated with the violent actions of the Luddites in response to the introduction of power looms in England many decades before 1886. Industrializing Belgium also experienced a few episodes of machinebreaking in the early nineteenth century: in 1808,1810,1819 and 1830 the wool workers of Verviers attacked shearing frames. During the Belgian revolution in August-September 1830 violence peaked in the cotton industry in Brussels. At the same time, in the mining district of the Borinage a small railway was destroyed. ${ }^{21}$ But after 1831 machine-breaking virtually disappeared. New instances of collective action against mechanization and deskilling were no longer destructive of property. Indeed, the dichotomy between old and new repertoires is too sharp to represent the complexity of historical reality: the Charleroi glassworkers show that occasionally a social group used entirely different forms of collective action at the same time.

\section{Local scope}

Claims were still aimed directly at the employers, and in a number of cases workers negotiated with local authorities, too. The patrons replied that they could not increase wages, however legitimate the workers' claims, because of their heavy losses and the enormous stocks piling up as a consequence of foreign competition. So the result of the negotiations was typically no settlement, no return to work. On every occasion, the employers appeared to be adamant in refusing to consider their workers' demands.

The local authorities were more willing to reconcile the clash between capital and labour. Their conciliatory attitude was mainly inspired by their

${ }^{21}$ Maurice Bologne, L'insurrection prolétarienne de 1830 en Belgique (Brussels, 1929), passim; Robert Demoulin, Guillaume ler et la transformation économique des Provinces belges (1815-1830) (Liżge, 1938), pp. 274-275; Jean Puissant, L'évolution du mouvement ouvrier socialiste dans le Borinage, pp. 106-107. 
concern for social peace, the maintenance of law and order being their direct responsibility. Yet they knew they would be incapable of wresting concessions from the employers since the latter were virtually immune from the antique "collective bargaining by riot" when there were large reserves of labour, large stocks and technological innovations. The declining importance of labour in the production process enabled employers to be stubborn. The Second Industrial Revolution of the 1870s and 1880s undermined the relative balance of interests and hence the subtle balance of power between industrial patrons on the one hand and skilled workers on the other. As a result of technological innovation, the industrial elite had the means to improve the "management" of the production process and to monopolize all the factors of production, labour included. Skilled workers lost control of their tools and their strong bargaining positions, making it possible for management to threaten their interests and privileges. Their status declined to that of other wage-earners; it meant the total proletarianization of the workforce and hence a loss of workers' bargaining power. The local authorities therefore adopted another strategy. They promised to mediate at the national level in favour of state intervention and protection.

\section{Political bargaining and reform}

How did Belgian workers in 1886 make history? What has been the political impact of the actions that culminated in the industrial jacquerie of 1886? The revolt held a political message that was clearly understood by powerful and less powerful factions within the national elite. Paradoxically, in March 1886 the actions and claims of the aggrieved Wallonon workers were anything but national or revolutionary. As we have seen, the interaction between collective actors in the political arena took place initially at a local and patronal level. However, the gap between capital and labour had become so unbridgeable as to make it virtually inconceivable that an employer would give in to the strikers' claims, with or without the intermediary efforts of local authorities.

The important twist of 1886 lies in the fact that the workers who did not intend to put pressure on those holding power at a national level did wrest concessions on a national scale similar to what Tarrow defines as a cycle of reform. He notes that cycles of reform often coincided chronologically with cycles of social protest. The example of the 1886 industrial jacquerie shows that there need not be a direct connection between the specific demands of a protest movement and its policy outcomes. Elites may respond with policy innovations that do not address specific grievances, but which aim to pacify insurgents. Reform is meant to contain workers' protests within institutionalized forms of political bargaining, which has the disadvantage for élites that contending groups are offered 
political access, and opportunities and incentives for further conflict at the same time. ${ }^{22}$

In order to establish the relationship between protest and reform in the context of 1886, the reader who is not acquainted with Belgian social history ${ }^{23}$ first needs to know the main lines of its social policy up to the last decade of the nineteenth century. Karl Marx described Belgium as "the model-state of continental capitalism, the comfortable paradise and hunting-ground of landowners, capitalists and priests". ${ }^{24}$ From independence in 1830 until the watershed of 1886 , successive governments largely ignored the social question. Laissez-faire, laissez-passer dominated not only economic policy, but also the approach of the government to the social conditions of the proletariat. To say that the credo of economic liberalism guided social policy does not mean that the ruling élites did not perceive there to be a social problem, though, nor that they did not develop strategies to overcome it. ${ }^{25}$ But these strategies unilaterally reflected the interests of entrepreneurs and the ruling élite. Furthermore, Belgium's ambiguous economic structure prevented global initiatives to regulate social reality, let alone any kind of social legislation.

Industrial entrepreneurs were concerned about the material and physical conditions of their workers only to the extent that they led to problems in recruiting labour and in controlling workers. It was for these reasons that measures were taken which favoured labourers; this was the case with the setting up of the Caisses de Prevoyance for the miners, for example. But this kind of intervention was limited and inadequate.

Although the interests of the different factions within the ruling classes diverged, they shared a common concern for the moral contingencies of the "working classes, dangerous classes". Improving the material conditions of working-class life, through regularized wage levels for example, was considered inconceivable. Industrial capitalists passed the effects of periodic crises on to the workers. The resulting fluctuations in wages, rising and falling according to the state of the economy, were simply justified by the fact that they were inevitable. So the livelihood of proletarians was made even more precarious than their very dependence on wages already implied. The underpaid labour of women and children (who were paid one-half to one-third of what were already low "normal" wages) was a necessary supplement to the income of the working classes. The social inferiority of the working classes was seen as an unavoidable correlate of

2 For this and other ideas on the relationship between struggle, reform and the state, see Tarrow, Struggle, Politics and Reform, pp. 91-103.

${ }^{23}$ B.S. Chlepner, Cent ans d'histoire sociale (Brussels, 1972) (4th edition), is still the standard work.

${ }^{24}$ Karl Marx and Friedrich Engels, La Belgique, etat constitutionnel modele (Paris, n.d.), pp. 285-286.

${ }_{25}$ Catharina Lis et al., Op vrije voeten? Sociale politiek in West-Europa (1450-1914) (Leuven, 1985), pp. 171-181. 
the struggle for life. The consensus on the inevitability of social exploitation corresponded with a consensus on the role of the state. Indeed, successive governments preached the ethos of non-interventionism in social affairs and took care not to disturb the free market.

The 1886 revolt undermined these views of non-interventionism profoundly. Without it, it is very unlikely that the ruling classes would have taken the interests of workers into account. The 1886 revolt was an eyeopener to the national authorities, who had hitherto ignored the grievances of industrial workers. Historians are, however, reluctant to do justice to the actors responsible for changing the policies of the government. Instead, it is the rulers who are acclaimed. The biographer of the Catholic statesman Auguste Beernaert, the leader of the government, praises him for his clairvoyance, for instance. He is called a precursor of social reform:

Sous le péril social, il avait discerné le mal social, c'est-ă-dire les misères et les injustices dont ces troubles n'étaient qu'un accident et qu'une conséquence. Il avait senti tout ce que la stricte doctrine manchestérienne comportait de faux et de dangereux en permettant au machinisme et à la libre concurrence d'aboutir en fait à une véritable exploitation de la main-d'oeuvre. ${ }^{26}$

The truth is that reformism cannot be attributed to the enlightened insights of the upper classes. Discourse like this tends to hide the transforming impact of collective action from below.

The industrial jacquerie of 1886 revealed the unbridgeable cleavage between capital and labour and presented the social question as diagnosed by the national political élite as a new and clear problematic issue. The consensus concerning laissez-faire in social policy was disturbed.

The shift is perceptible in three different ways: first, the government responded with symbolic gestures that can not be brushed aside as tokenism; second, an ambitious government inquiry into the world of labour led to substantive social legislation, a kind of code de travail that offered modest state protection to workers; third, in the realm of electoral politics the political weight of the radical wings within the traditional parties increased, and the POB became a political force to be reckoned with. In short, as a result of popular struggle outside the conventional limits of politics, the political system was opened up to workers' claims.

The first symbolic statement of the shift in social policy was a report to the king, signed by Auguste Beernaert. In covert terms it said that industrial capitalism caused unexpected difficulties and antagonisms between capital and labour. Consequently, the state had to take account of workers' grievances: "Le sort des ouvriers doit faire plus particulièrement l'objet de la sollicitude des pouvoirs publics [ . . . ] le problème de l'amélioration du sort de l'ouvrier s'impose plus que jamais à l'attention de tous."

${ }^{26}$ Henri Carton de Wiart, Beernaert et son temps (Brussels, 1945), pp. 79-82.

${ }^{27}$ Report to the king, 14 April 1886. Belgian Statute Book, 17 April 1886. 
The report announced the setting up of the Commission d'Enquête du Travail. It is remarkable that it was Lieutenant-General Van der Smissen of all people who was the first to advise the king informally to appoint a "commission d'enquête . . . sur les conditions d'existence des travailleurs ainsi que sur ce qu'il conviendrait de mettre en pratique pour améliorer leur sort, tant dans le présent que dans l'avenir". Van der Smissen had actually considered talking with the workers on strike, and it had struck him that they were so convinced that nobody - shareholders, managers, the government, not even the king - bothered about them, and this left them utterly discouraged. ${ }^{28}$ As a result of the revolt, workers' complaints were eventually recognized in the Commission d'Enquête du Travail, appointed on 28 April 1886.

The crucial reason why the élites gave workers this kind of hearing was only articulated behind the scenes of public life. The governor of Eastern Flanders, for instance, drew the attention of the Minister of the Interior to the fact that, unlike other groups, the working class had no legal channels it could use to voice its grievances. He added that this institutional flaw led them to take more radical measures: "Souvent lorsqu'une classe ne peut exercer légalement l'influence qu'elle croit avoir, elle cherche a l'exercer par des moyens révolutionnaires." 29

The important speech by the king on the occasion of the opening of Parliament in November 1886 announced new directions in government policy and showed that these considerations were being taken into account. The king confirmed that workers had to be protected by the state against the abuses of unfettered capitalism:

La situation des classes laborieuses est hautement digne d'intérêt et ce sera le devoir de la législature de chercher, avec un surcroît de sollicitude, à l'améliorer. Peut-être a-t-on trop compté sur le seul effet des principes d'ailleurs si féconds de la liberté. Il est juste que la loi entoure d'une protection plus spéciale les faibles et les malheureux. ${ }^{30}$

Beernaert's report, the appointment of the Commission and the king's speech were the first signs of a changed strategy, grounded in a new problematization of the social question. These symbolic gestures were followed by a series of reforms which were meant to preclude a repeat of the events of March 1886.

The conclusions of the Commission d'Enquête du Travail ${ }^{31}$ formed the basis of a cautious body of social legislation announcing the introduction

\footnotetext{
23 Van der Smissen to King Leopold II, 7 April 1886. Archives Royales, Bruxelles, Correspondance Leopold $11,551$.

29 Governor of Eastern Flanders to the Minister of the Interior, 27 March 1886. Archives de l'Etat a Beveren-Waas, Province de la Flandre Orientale, G/38/1.

${ }^{30}$ Annales Parlementaires, 1886-1887, p. 10.

${ }^{31}$ The report of the Commission d'Enquête du Travail, was published in four volumes between 1887 and 1888 .
} 
of a system of social security and labour protection through state intervention: laws were introduced in $\mathbf{1 8 8 7}$ to protect workers and to ensure wages were paid in cash (the truck system was abolished), industry and labour councils were established and charged with arbitrating in industrial disputes (1887), labour inspection began (1888), and laws restricting child labour and female employment and regulating workers' housing were introduced (1889). ${ }^{32}$

These laws might be seen as the first phase of a cycle of reform that extended from 1895 onwards and was pressed on the government by the labour movement, which had gained a degree of electoral power by 189394. In practice, workers did not perceive drastic changes in their living conditions; nor did social legislation weigh too heavily on the state's budget nor the freedom of industrialists in the labour market become too severely restricted. Nonetheless, the basis of the code de travail was laid and could not easily be retreated from.

The new course in social policy was maintained, though very slowly. The non-interventionists continued to exert a considerable influence on political decision-making, but the revolt of 1886 had infringed irreversibly upon their electoral power.

First of all, the Labour party entered the political scene with more vigour than at the time of its foundation. On 5 April 1885, a hundred representatives of fifty-nine socialist associations of various kinds had succeeded in setting up the POB. The POB was a loose association of local labour organizations (political leagues, syndicats, co-operatives, mutual benefit associations) and groups of radical intellectuals operating in Flanders and in Brussels. With the sole exception of the Ghent co-operative Vooruit, which was an association of factory workers, all the labour associations represented at the first assembly of the POB had their roots in skilled pre-industrial crafts. Nevertheless, the party had to become (and did become) a huge movement incorporating all workers (hence the substitution of the labelling adjective "socialist").

The POB's main goal was the political emancipation of the working classes through universal suffrage. United, the working class would be able to achieve a parliamentary majority and hence to carry through social reforms. In the spring of 1886 , only the POB had a significant programme of social reform, but it was powerless, having no seats in parliament. ${ }^{33}$

As a result of the events of March 1886 and the growing support for the socialists, the position of the reformist wings in both the Liberal and Catholic parties strengthened. There were an increasing number of progressives

32 See B.S. Chlepner, Cent ans d'histoire sociale, pp. 208-234; Jean Puissant, "1886, la contre-réforme sociale", in Pierre Van der Vorst (ed)., Cent ans de droit sociale belge Honderd jaar Belgisch sociaal recht (Brussels, 1988), pp. 69-102.

${ }^{33}$ Maxime Szteinberg, "La fondation du P.O.B. et le ralliement de la classe ouvrière a l'action politique (1882-1886)", International Review of Social History, 8 (1963), pp. 128 215. 
within both parties, and they became more critical of their conservative allies, supporting the POB on the issue of social legislation and state protection.

The only tie that held the conservative and radical Liberals together was their anticlerical opposition to the Catholic government. The Catholics were able to hold on to power between 1884 and 1914 partly as a result of the weakness of the profoundly divided Liberal Party. The progressive wing within the Liberal Party opposed the conservative noninterventionists and advocated the extension of citizenship to workers and the introduction of a programme of social legislation.

A similar division was produced among Catholics by the industrial jacquerie. In September 1886 they organized an important congress on the social question in Liège. Here one group opposed economic liberalism and wanted Christian, ultramontane solutions to the social question, which meant primarily a return to the idealized past before the French Revolution. This group was influential in convincing Catholic politicians of the need to deal with workers' problems in a paternalist and corporatist way, but it was against state intervention. The Christian Democrats were able to express themselves publicly for the first time as a result of this congress. This democratic minority held that the revolt in March proved that private initiative was insufficient in a changed socio-economic era. The ruling classes had not lived up to their responsibilities. Social abuses had to be corrected by legislative reforms. The views of these democrats, who were in a minority in 1886, were later supported in the 1890s by Pope Leo XIII's encyclical letter Rerum Novarum. ${ }^{34}$

The various responses on the part of the political élites did mean a break with the past. The consensus on the importance of the laissez-faire model in social policy was irreversibly broken, giving way to state intervention and social legislation providing for embryonic forms of social security and institutional negotiation in labour conflicts. The disruptive power of the events of 1886 , the distorted, but nonetheless frightening, picture of a furious mass revolt turning the world upside down is causally linked with social reform in the last decades of the nineteenth century.

\section{Changing repertoires of collective action in Belgium}

The cumulative impact of the industrial jacquerie and the reformist tendency opened a new chapter of collective popular action in Belgium. The dramatic spring of 1886 was thus a watershed in workers' repertoires of collective action. As we have seen, by March 1886 no organized mass movement of workers had yet come into existence. If, following Tilly, we

34 Paul Gérin, "1886 et le monde catholique", and Eliane Gubin, "Les événements de 1886 et le monde liberal", in Marinette Bruwier et al. (eds.), 1886. La Wallonie née de la greve? (Brussels, 1990), pp. 51-92. 
define a social movement as "a sustained challenge to state authorities in the name of a population that has little formal power with respect to the state", then the organized labour movement that existed before 1886 in Belgium can hardly be described as a social movement; this labour movement did not challenge national state authorities in a sustained way.

Tilly sees a strong connection between the emergence of national social movements and the rise of mass electoral politics in France and Britain. ${ }^{35}$ But Belgium's closed political élite and restricted suffrage hampered the development of a social movement oriented towards national electoral goals. The Belgian constitution of 1830, "the most liberal in Europe", declarations of the equality of citizens notwithstanding, reserved suffrage and political institutions for a small tax-paying élite. The Paris Revolution of 1848 induced fear among Belgium's political élite and resulted in a lowering of the tax threshold, but the extension of the right to vote did not affect the working class. Most workers continued to be excluded from national politics until bourgeois democracy was gradually extended to include them between 1886 and $1921 .^{36}$

The liberal constitution of 1830 , with its freedom to demonstrate and to hold public meetings, promoted new repertoires of collective action long before the working-class social movement actually took shape. It was not until 15 August 1880, however, that the first national demonstration for universal suffrage took place in Brussels. The demonstration proved to be a flop. The Royal Attorney reported that only 2,000 people took part. ${ }^{37}$ The labour movement simply was not able to mobilize mass support in 1880 . Between 1880 and 1886 the socialists directed their political resources even more towards electoral goals. The key to attaining these goals was the mobilization of the Walloon workers employed in the heavy industries. They represented the numerical strength needed to create a genuine mass movement. The problem was that they were hardly involved in the foundation of the POB. The POB programme initially found little response among the workers of Wallonia; nor did the party succeed in organizing them.

Things began to change with the publication of a pamphlet, Le Catéchisme du Peuple. This pamphlet, which had been circulating in Wallonia since the beginning of March 1886, was a bestseller. It was commissioned by the $\mathrm{POB}$ to be used in its first nationwide campaign for a mass demon-

33 Charles Tilly, "European Violence and Collective Action since 1700"; Social Research, 53 (1986) 1, pp. 159-184; idem, Social Movements, Old and New." In Louis Kriesberg et al., Social Movements as a Factor of Change in the Contemporary World, pp. 1-28; Collective Violence in European Perspective", in Ted Robert Gurr (ed.), Violence in America: Volume 2. Protest, Rebellion, Reform (Newbury Park, 1989).

${ }^{36}$ Eric J. Hobsbawm, The Age of Empire: 1875-1914 (New York, 1987), pp. 84-111; Els Witte et al., Politieke geschiedenis van Belgie. Van 1830 tot heden (Antwerp, 1990) pp. 121127.

37 Archives Générales du Royaume a Bruxelles, Parquet-Général, 219. 
stration in favour of universal suffrage, planned to be held in Brussels on 13 June 1886. The aims of the POB and the methods it intended to achieve them were stated in the seventh lesson of the catechism:

5. Que dois-tu faire?

R. Abolir l'esclavage dans lequel nous vivons.

6. Comment dois-tu y arriver?

R. Par le suffrage universel.

7. Comment l'obtiendras-tu?

R. En allant tous, de tous les coins de Belgique le demander à Bruxelles.

8. Peut-on t'empêcher d'aller à Bruxelles?

R. Non. J'use de mon droit comme les soi-disant libéraux et catholiques en ont usé en septembre 1884.

9. Il te faut de l'argent pour aller à Bruxelles.

R. J'irai à pied.

10. Triompheras-tu?

R. Oui, car mon cri de ralliement sera: Vive le peuplel vive le suffrage universel!

11. Marchons alors?

R. Oui marchons! en avant! et vive le peuple! vive le suffrage universel!

12. A quand le rendez-vous?

R. Le jour de Pentecôte tous les Borains seront à Bruxelles; ils y arriveront à pied et y trouveront 25,000 gantois, 20,000 liégeois et verviétois, 20,000 ouvriers du Centre et de Charleroy. Tous les ouvriers y seront réunis, le peuple entier y sera et le gouvernement nous donnera le suffrage universel aux cris de: Vive le peuple! Vive la liberté ${ }^{38}$

It is clear that the author of this catechism, Alfred Defuisseaux, did not intend to mobilize the workers in March 1886. Notwithstanding the fact that the pamphlet met a ready market in the industrial regions, its influence on the revolt was at most indirect. Even so, the protesters must have recognized that it contained a striking expression of their grievances.

But the collective actions which took place in 1886 did not in the least correspond to the forms by which the POB wanted labour protest to be expressed. The party was apprehensive of stepping beyond the legal constraints on non-institutionalized political action. A peaceful mass demonstration in the capital was a legitimate right, difficult to deny the labour movement since other movements had used it many times before. So the POB promoted the mass demonstration in Brussels, with parliament and the national government as its targets. Labour protest had to become offensive in order to gain power within the framework of national politics, and it became offensive through the struggle for universal suffrage.

The mainly defensive protests in 1886 had alarmed the POB's leaders as much as the political establishment. The POB reacted strategically by demonstrating the need for powerful strike-supporting organizations to avoid bloodshed. In an extensive report to the government, the head of the secret police noted:

39 Alfred Defuisseaux, Le Catéchisme du Peuple (Brussels, 1886), p. 16. 
Les chefs du mouvement socialiste, un moment déroulés par cette explosion soudaine de violences, reprirent bientôt l'oeuvre commencée et trouvèrent un courant favorable dans le découragement qui suivit la répression, dans la misère augmentée par des grèves irréfléchies, dans les rancunes qu'allaient faire naître les condamnations prononcées. ${ }^{39}$

A greater emphasis on the link between social claims and universal suffrage was the key to mobilizing the rank and file in the struggle for political emancipation.

From April 1886 onwards, POB meetings multiplied in the regions of Liège and Hainaut. Every Sunday, militants tried to convince workers even in the remotest corners of Wallonia to participate in the demonstration of 13 June. The propagandists held that Belgian laws were voted on by the representatives of just 120,000 people; 2 million people had no say. Laws thus favoured the interests of the wealthy against those of the workers, who slaved to support the rich in their opulence. Often, the fund workers set up to pay the costs of the trip to Brussels was the starting point for a local workers' league that later joined the POB. The secret police called this campaign a genuine crusade against capital. ${ }^{40}$

The campaign did succeed in creating a resonance with the mass base of support that the POB needed to make its claim credible. In as early as May the Royal Attorney of Charleroi noted that the miners were hoping for a significant change in the relation between them and their patrons and perhaps in their position in society as a whole: they believed that the demonstration in June would bring that change about. ${ }^{41}$ But, mindful of the events of March, the demonstration was prohibited. For the first time in Belgium's history, the mayor of Brussels used his right to forbid demonstrations pre-emptively. He was urged to do so by the government. King Leopold noted that "the politics of the streets" was a danger that had to be averted. ${ }^{42}$

The demonstration was authorized only when the threat of social unrest had significantly diminished. On 15 August 1886, the POB mobilized around 20,000 workers, predominantly industrial workers from the provinces. The success of this action did not escape the attention of the authorities:

\footnotetext{
39 "L'agitation ouvrière en Belgique a la fin de 1886", Report by the head of the secret police, 1 February 1887. Archives Royales, Leopold II - Troubles, greves, manifestations violentes, attentats, 2085.

* "Chaque dimanche quelque délégué bruxellois pour les provinces wallonnes, quelque beau parleur gantois ou anversois pour les localités flamandes, part pour quelque localité ou il rejoint un ou deux orateurs de cra; on organise un bout de manifestation, avec musique si faire se peut et drapeau rouge obligé; puis pendant une heure on excite les appétits et les haines du travailleur contre la classe bourgeoise." Ibid.

41 Archives Générales du Royaume a Bruxelles, Parquet-Général, 224.

42 Leopold to Beernaert, 24 May 1886, published in Edouard Van der Smissen, Leopold II et Beernaert d'apress leur correspondance inédite de 1884 d 1894 (Brussels, 1920), I. pp. 93-95.
} 
Il est incontestable qu'après être pendant des années restés sourds aux prédications socialistes, les travailleurs industriels des bassins de Liège, Verviers, Charleroi, du Centre, du Borinage, sont sortis de cet état de torpeur et se remettent en mouvement. Ce résultat a donné aux chefs du Parti ouvrier une confiance énorme. ${ }^{43}$

The claim for universal suffrage had gained its force. In March 1886 the cry for universal suffrage had not been made. Only a few months later this claim deafened the streets of Brussels and inundated the officials of the Commission d'Enquête du Travail who questioned the working class on their grievances. The Canadian historian J.A. Frank argues that the fact that the overwhelming majority of responses to the inquiry were "political" is crucial evidence to support his thesis that the March insurrection was not an industrial jacquerie but an action inspired by "political" claims. There was indeed a high level of "political consciousness", but clearly Frank does not take into account the rapid, significant reorientations within the labour movement that took place between the spring and summer of $1886 .^{44}$

The interaction between the wave of popular mobilization and the strategies of the organized labour movement fostered the collective creation of new frames of meaning crystallizing in the cry for universal suffrage. Without the resonance created by the speeches of POB activists on ordinary workers, the claim would have remained pointless. Along with this transformed political consciousness, 1886 also created new popular heroes. The political and judicial establishment wrongly stigmatized and sentenced a number of $\mathrm{POB}$ protagonists, among them the author of Le Catechisme $d u$ Peuple, together with the foremen of the Union Verrière as the moral leaders responsible for the violent disorder. The POB's leaders were not in fact involved at all, and they did everything they could to disclaim responsibility for actions they found insensitive and pointless. But their trials and convictions as agitators enhanced their popularity in a way they could not have imagined.

In the last decade of the nineteenth century the organized labour movement became the mouthpiece for workers' claims and interests in the political arena. The experience of 1886 became a symbol of passionate strife stifled in blood. As I have tried to show, the industrial jacquerie functioned as a catalyst in the transition from old to new repertoires of collective action. Its symbolic qualities contributed to the gradual standardization, formalization and centralization of demonstrations and strikes. The display of strength and commitment in the increasing number of mass demonstrations and general political strikes from 1886 onwards was effective to the degree that it gradually extended the right to vote to people who had previously no institutional power. ${ }^{45}$

43 "L'agitation ouvrière".

" Frank, "L'insurrection belge de 1886", pp. 169-174. See also Puissant, "1886, la contreréforme sociale?"

is See Janet L. Polasky, "A Revolution for Socialist Reforms: the Belgian General Strike for Universal Suffrage", Journal of Contemporary History, 27 (1992), pp. 449-466. 
As in England and France, the emergence of social movements was closely connected with the growth of national electoral politics. In Belgium, the struggle for universal suffrage by the $P O B$ displaying the characteristics of a social movement actually ushered in an era of mass democracy. The making of mass democracy was the result of conflict between the labour movement on the one hand, claiming suffrage and institutional power by means of demonstrations and general strikes, and the ruling élite on the other, who responded to this challenge by means of a gradual extension of democracy in order to safeguard capitalism and avoid losing power.

All this cannot be explained merely by referring to the endeavours of the leaders organizing the labour movement. The effectiveness of the new repertoire was determined ultimately by the experiences, interests and aspirations of the rank and file.

\section{Conclusions}

A single case study cannot hope to offer much in the way of comparison. But I hope I have helped suggest questions that might inform comparative research on the transforming impact of collective action in other times and places. One important and ambitious question is, I believe, under what conditions ordinary people were able or unable to make and change history. Important, because it stems directly from the "history from below" quest for traces of the apparently inarticulate grassroots. Ambitious, because it requires a comparative study of the closely related problems highlighted by Charles Tilly and Sidney Tarrow as being significant for researchers. Indeed, the ability of ordinary people to make history depends, first, on the conditions of collective action. The question under what conditions people act collectively, or fail to do so, leads us to Tilly's conceptual framework that stresses (among other things) the organizational base behind claim-making, the risks (including repression) of mobilization, the opportunities offered by political alignments, and the changing repertoires of collective action produced by major structural changes in capitalism and state formation. Sidney Tarrow goes one step further and asks under what conditions collective action is successful, i.e. when it is linked with reform and innovation.

The Belgian industrial jacquerie of 1886 shows how and why workers who had no formal organization and no institutional power within the political structure of the state were able to mobilize a mass movement and to influence policy. Their risky and costly struggle forced the state to intervene in labour conflicts. The link between protest and reform was determined more by the disruptive and revealing characteristics of the events than by either the political opportunities available, the capacity to mobilize supporters, or the instability of political alignments. The transforming impact of the collective action itself created new conceptions of the role of the state, new political opportunities, and fuelled a new repertoire of collective action. 